\title{
ORGANIZATIONAL CITIZENSHIP BEHAVIOR IN THE CONSTRUCTION OF ISLAMIC BOARDING SCHOOL: A STRUCTURAL MODEL
}

\author{
Lili Karmela Fitriani*, Linda Wulandari \\ Universitas Kuningan, Indonesia
}

\begin{abstract}
Problems of organizational citizenship behavior among academics, especially teachers in Islamic Boarding Schools, are underrepresented in previous studies. This research was conducted at Islamic Boarding Schools in Kuningan in the context of organizational quality. This study aims to determine the influence of Employee Engagement and Job satisfaction on Organization Citizenship Behavior through Job Organization commitment as an intervening variable. This study includes a type of comparative causal research with a quantitative approach using questionnaires to 130 respondents. The result shows that Employee Engagement and Job satisfaction have a significant effect on Organization Commitment. Employee Engagement, Job Satisfaction, and Organization Commitment have a significant effect on Organizational Citizenship Behavior.
\end{abstract}

Keywords: Employee Engagement; Job satisfaction; Organization Commitment; Organizational Citizenship Behavior

*Corresponding Author : $\underline{\text { lili@ } @ \text { uniku.ac.id }}$

DOI: $10.24252 /$ minds.v8i1.21034

ISSN-E: 2597-6990

ISSN-P: 2442-4951

http://journal.uin-alauddin.ac.id/index.php/minds

Publisher: Program Studi Manajemen, Universitas Islam Negeri Alauddin Makassar 


\section{INTRODUCTION}

Human resources are a critical element of an organization because of its human role as a planner, executor, and supervisor of all organizational activities. Other resources cannot be utilized or managed correctly without human resources, so every organization needs human resources to work effectively to achieve organizational goals. Similarly, boarding schools' rapid development constantly improves human resources improvement, transforming and innovating, based on better management methods. So is the content (material) to create a more quality education as the demands of changing times. These changes have made much progress in boarding schools.

Boarding schools are expected to shape intellectual, emotional, and religious character formation so that graduates possess noble morals and character. The average team member, namely teachers, educators, and caregivers at boarding schools, must work almost 24 hours and help each other achieve boarding school. The behavior of individuals (employees) becomes the determinant of achieving the goals that are to be performed by boarding school graduates of the character. Therefore, the employees in question are teachers, educators, and caregivers at boarding school in its implementation must have: behavior to help others (altruism), conscientiousness, sportsmanship, maintaining good relations (courtesy), and civic virtue (Organ in Muhdar, 2018: 1 ). In reality, what happens at boarding schools in the absence of mutual support or help between employees because they work 24-hour. This phenomenon describes the existence of employees who do not meet the OCB dimension in the form of altruism, where employees help other employees without any coercion on tasks related to the organization

Putri (2018) explains that high work quality is an organizational demand shown not only through in-role behavior but also extra-role. In-role behavior is doing work following the job description tasks, while extra-role behavior is doing work outside the job description without expecting a compliment and reward. They are commonly referred to as Organizational Citizenship Behavior.

According to Robbins \& Coulter (2010), organizations with organizational citizenship behavior organizations are superior to organizations without these employees. This argument is endorsed by Meilina (2017), who believes that companies can significantly benefit from having OCB workers because they produce efficiency that exceeds goals and conduct work that exceeds duties. Organizations must then consider the $\mathrm{OCB}$, and if the organization lacks it, it would affect increasing anomalies in team member behavior and reducing the social dimensions of the organization.

Empirical researches show a significant impact of team member engagement, job satisfaction, and organizational commitment on Organizational Citizenship Behavior. The study by Sridhar \& Thiruvenkadam (2014) showed that team member engagement significantly impacts organizational citizenship behavior. Pavalache-ilie (2014) found a significant effect of job satisfaction on organizational citizenship behavior. Another study by Zayas-Ortiz et al. (2015) 
showed that organizational commitment positively and significantly impacts organizational citizenship behavior. Triwibowo \& Arsanti (2016) suggested that several Organizational Citizenship Behavior studies place organizational commitment as a variable that mediates the impact of certain variables on Organizational Citizenship Behavior.

However, there are different research results. According to Putrana et al. (2016), job satisfaction does not impact Organizational Citizenship Behavior. The concept of Organizational Citizenship Behavior is voluntary behavior without taking direct compensation into account and contributing to the workplace's psychological and social environment (Darto, 2014).

Organizational citizenship behavior can be affected by several causes; one of those is team member engagement. Robbins \& Judge (2015) states that employee engagement is the interest, satisfaction, and passion of a person for their work. They may have strong knowledge about taking on an additional role with the job and the company while the employee is engaged in their workplace.

Organizational Citizenship Behavior (OCB) is also affected by job satisfaction. Wibowo (2016) argued that the primary determinant of staff's Organizational Citizenship Behavior is job satisfaction. More satisfied employees will say positive things about the organization, help other colleagues, and exceed normal work expectations. Furthermore, OCB is also affected by organizational commitment. Employees who have high administrative obligations will provide maximum work results and even exceed corporate expectations.

\section{LITERATURE AND MODEL DEVELOPMENT}

\section{Organizational Citizenship Behavior}

Organizational Citizenship Behavior is the acts of employees outside their roles (Wibowo, 2016). Meanwhile, according to Meilina (2017), Organizational Citizenship Behavior is the actions of workers who can operate without earning rewards for their ability to exceed the indicated criteria. According to Robbins \& Judge (2015), Organizational Citizenship Behavior leads to the psychological and social climate of the workplace as altruistic behavior. According to Organ (in Meilina, 2017), Organizational Citizenship Behavior has five primary dimensions, as follows: Altruism, Civic Virtue, Conscientiousness, Courtesy, and Sportsmanship. Podsakof (in Darto, 2014) explains that to boost operational efficiency, Organizational Citizenship Activity is advantageous.

\section{Employee Engagement}

William Kahn first introduced employee engagement in 1990, which states that employee engagement uses a member in the organization for their respective job roles by using and expressing oneself, both physically, cognitively, and emotionally. Robbins \& Judge (2015) notes that an individual's commitment, happiness, and passion for their job is employee engagement. Meanwhile, Noe (in Puspadewi, 2016) defines employee engagement as the extent to which 
employees are fully engaged in work to strengthen their commitment to work. Sridhar \& Thiruvenkadam (2014) have shown that the association between employee engagement and OCB is positive. It was clarified that there was a favorable association between employee engagement and $\mathrm{OCB}$, in line with Amanda's (2014) research findings, indicating that the higher employee engagement, the higher the Organizational Citizenship Behavior.

Other research results by Chhetri (2017) found that employee engagement is a predictor of OCB and has a positive relationship with OCB. Furthermore, Fauziridwan et al. (2018) indicated that employee engagement would contribute to Organizational Citizenship Behavior since it focuses on employee participation and engagement. Thus, employee engagement will improve Organizational Citizenship Behavior. Saragih \& Margaretha (2013) suggest that highly engaged employees will be more committed to work and organization. Furthermore, Puspadewi (2016) identified a positive and essential link between employee engagement and organizational commitment. Employee engagement has a positive and crucial association with organizational commitment, in line with the research findings of Haryanto et al. (2018). Thus, it can be concluded that employee engagement is closely related to organizational commitment and positively relates to organizational commitment.

\section{H1: Employee engagement affects organizational commitment}

H2: Employee engagement affects $O C B$

\section{Job Satisfaction}

Handoko (2012) explains job satisfaction as a positive or negative mental condition for a job. Job satisfaction is directly connected to employee perceptions about different aspects of employment, including the state at work, social effects at work, compensation, and leadership. Job satisfaction is a good job created by evaluating specific features (Robbins \& Judge, 2015). Meanwhile, Umam (2010) notes that job satisfaction is a worker's attitude toward the job that emerges based on analyzing the work situation. Job satisfaction depends on the appropriateness or equilibrium between what is anticipated and truth.

According to Luthans (2011), several dimensions affect job satisfaction, including the following: The work itself, Promotions, Supervision, Workgroup, and Working conditions. More specific impacts of job satisfaction and dissatisfaction are as follows: Robbins \& Judge (2015), Job Satisfaction and Performance, Job Satisfaction and Organizational Citizenship Behavior, Job Satisfaction and Absence, Job Satisfaction and Worker Turnover, Job Satisfaction and Deviations in the Workplace.

Buhali \& Margaretha (2013) clarified that work satisfaction has an essential connection with organizational commitment. In line with Cahya Utama \& Wibawa's research (2016), job satisfaction has a positive relationship with organizational commitment, meaning that if job satisfaction increases, the organizational commitment will increase. Furthermore, Triwibowo \& Arsanti (2016) suggest that employees who work happily will give good results and foster devotion to the organization. Meanwhile, Haryanto et al. (2018) indicated 
that a satisfied employee tends to be absent less frequently, makes positive contributions, and feels at home in the organization. Employees who are pleased with work have a more profound devotion to their place of work. It can also be inferred that job satisfaction is closely linked to organizational involvement and positively correlates with organizational engagement.

Wibowo (2016) indicated that the critical aspect of organizational citizenship behavior for workers is job satisfaction. More satisfied employees will say positive things about the organization, help other colleagues, and exceed normal work expectations. Nwibere's (2014) research findings indicate that job satisfaction has a good and robust association with OCB, which means that OCB will improve if job satisfaction improves. Another study by Kiswari et al. (2016) showed that job satisfaction has the most dominant OCB relationship. Furthermore, Triwibowo \& Arsanti (2016) explained that in many research results related to $O C B$, it had been identified that job satisfaction is a potential predictor of OCB. Besides, Cahya Utama \& Wibawa (2016) explained that an increase in job satisfaction would affect employee's OCB, which will positively influence company goals. Pavalache-ilie (2014) found that job satisfaction has an essential effect on Organizational Citizenship Behavior.

H3: Job satisfaction positively affects Organizational commitment

H4: Job satisfaction positively affects OCB

\section{Organizational Commitment}

Lutans (2011) argued that organizational commitment is a mindset expressing workers' commitment to the company and the continuous phase in which executive members demonstrate their support for the organization and its continued growth. Furthermore, Wibowo (2016) described organizational commitment as the emotions, behaviors, and actions of people who consider themselves part of the organization, are active in administrative activities, and are committed to achieving organizational objectives. Meanwhile, Robbins \& Judge (2015) describe organizational commitment as the individual's relative strength in defining their participation in the organization, characterized by the acceptance of corporate values and objectives, the willingness to work for the organization, and the desire to maintain membership the organization. Meyer and Allen (in Umam, 2010) formulate that there are three dimensions of commitment in an organization, namely as follows: Affective Commitment, Continuance Commitment, and Normative Commitment.

Triwibowo \& Arsanti (2016) explained that the employee would do whatever it takes to advance the organization when they have a high dedication to the organization because they believe in the organization. Zayas-Ortiz et al. (2015) explained that organizational commitments and OCB have a positive relationship. In line with the results of research by Kusumaninggati et al. (2018), Organizational commitment has a positive and essential correlation with OCB. It can be said that when an employee's organizational commitment increases, their OCB will also increase. Another study by Muhajir \& Arisandra (2018) showed 
that organizational commitment is positively and substantially linked to OCB and organizational engagement is more critical than job satisfaction, which means that the OCB of an individual would be more outstanding with organizational commitment. Therefore, it can be inferred that organizational commitment is closely connected to OCB and positively associated with OCB.

H5: Organizational Commitment affects $O C B$

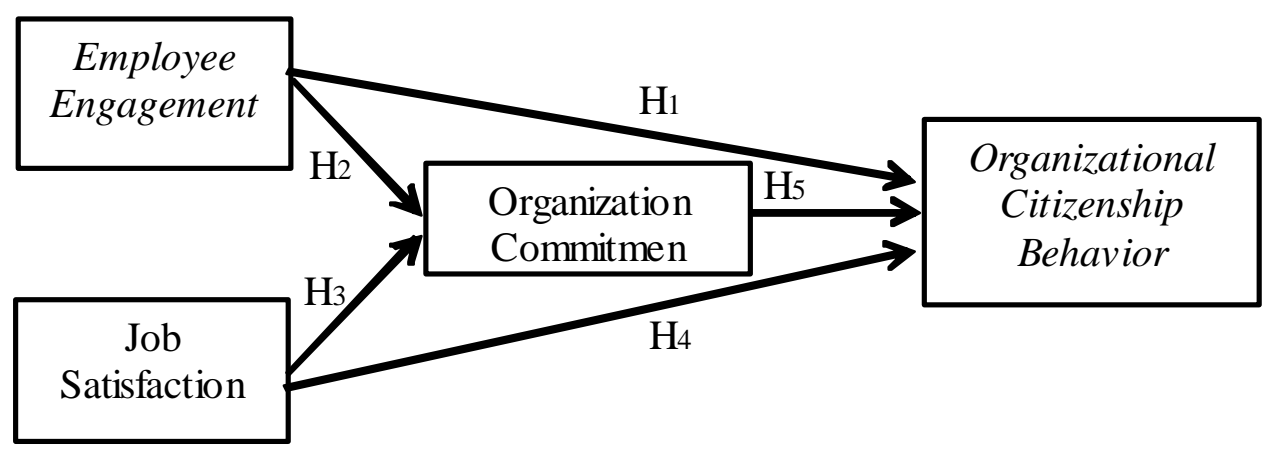

Figure 1. Empirical Research Model

\section{METHODOLOGY}

The data used in this study are opinions, attitudes, experiences, or characteristics of study subjects (respondents). In this case, the primary data is obtained from a respondent. The survey method is selected to approach the respondents by a series of closed-ended questions. The secondary information consists of teaching staff (teachers) and management as many as 130 people in purposive random sampling from selected boarding houses in Kuningan. The selection of this organization is based on the specific information and minimum discussion in the context of Islamic boarding schools. Unlike other organization, the Islamic boarding school work 24 hours and closely related to the students in a specific environment. This condition provides further context on the OCB discussions. The analysis method employs SEM-AMOS in the analysis. The tool provides data of the goodness of fit index and a model specification in path coefficient revelations.

\section{RESULT}

This research uses Structural Equation Modeling (SEM) that demands several criteria, namely, evaluating conformity criteria for testing the model feasibility index (goodness of fit). The processing results in the analysis of confirmation factors of Information Technology and Innovation show that all indicators used to form this research model have met the standard. Table 1 displays the finding as all values of Chi-Square, CFI, TLI, CMIN/DF, and RMSEA within the required range. Thus, the construction used to form the research model has met the model feasibility criteria. The model hypothesis test indicates that this model corresponds to the data. Table 1 summarizes the goodness of fit test. 
Table 1. Summary of Goodness of Fit Index

\begin{tabular}{lccc}
\hline \multicolumn{1}{c}{$\begin{array}{c}\text { Goodness of Fit } \\
\text { Index }\end{array}$} & $\begin{array}{c}\text { Cut-off } \\
\text { Value }\end{array}$ & Result & Evaluation \\
\hline Chi-Square $(\mathrm{df}=54)$ & $<72,153$ & 63,617 & Good \\
Probabilty & $>0.05$ & 0,159 & Good \\
RMSEA & $\leq 0,08$ & 0,047 & Good \\
GFI & $\geq 0,90$ & 0,949 & Good \\
AGFI & $\geq 0,90$ & 0,909 & Good \\
TLI & $\geq 0,95$ & 0,993 & Good \\
CFI & $\geq 0,95$ & 0,995 & Good \\
\hline
\end{tabular}

The hypothesis is derived and tested by statistical tests in path analysis. Statistical tests of processing results with SEM are carried out by looking at the significance level of the relationship between the variables indicated through the Probability (p) and Critical Ratio (C.R.) values, respectively. The statistical evidence reveals the ability of each indicator represents the respected variables in table 2.

Table 2. Standardized Regression Weight

\begin{tabular}{|c|c|c|c|c|c|c|c|}
\hline & & & Estimate & S.E. & C.R. & $\mathrm{P}$ & Label \\
\hline $\mathrm{X} 4$ & $<--$ & $\mathrm{EE}$ & 1,000 & & & & \\
\hline X3 & $<---$ & $\mathrm{EE}$ & ,969 & ,038 & 25,514 & $* * *$ & par_1 \\
\hline $\mathrm{X} 2$ & $<--$ & $\mathrm{EE}$ & 1,046 &, 030 & 15,345 & $* * *$ & par_2 \\
\hline X1 & $<---$ & $\mathrm{EE}$ & 715 & ,090 & 7,922 & $* * *$ & par_3 \\
\hline $\mathrm{X} 7$ & $<---$ & KK & 1,000 & & & & \\
\hline $\mathrm{X} 8$ & $<---$ & KK & 1,077 &, 042 & 25,530 & $* * *$ & par_4 \\
\hline X9 & $<---$ & KK & ,930 &, 058 & 16,042 & $* * *$ & par_5 \\
\hline $\mathrm{X} 10$ & $<---$ & KK &, 721 & ,094 & 7,670 & $* * *$ & par_6 \\
\hline $\mathrm{X} 11$ & $<---$ & KK & ,938 & ,060 & 15,529 & $* * *$ & par_7 \\
\hline $\mathrm{X} 12$ & $<---$ & KK & 1,016 & ,049 & 20,609 & $* * *$ & par_8 \\
\hline $\mathrm{X} 13$ & $<--$ & KK & ,976 &, 058 & 16,951 & $* * *$ & par_9 \\
\hline $\mathrm{X} 14$ & $<---$ & KK & 879 & ,065 & 13,530 & $* * *$ & par_10 \\
\hline
\end{tabular}

The full model test results showed the full model feasibility test index value as follows (goodness fit index) is $\chi^{2}=277,812$, Probability $=0.377$, TLI $=$ 0.996, $\mathrm{CFI}=0.997, \mathrm{GFI}=0.938, \mathrm{AGFI}=0.915, \mathrm{DF}=249, \mathrm{CMIN} / \mathrm{DF}=1.116$ and RMSEA $=0.013$. The model is fit so that the analysis results can be seen in Figure 2: 


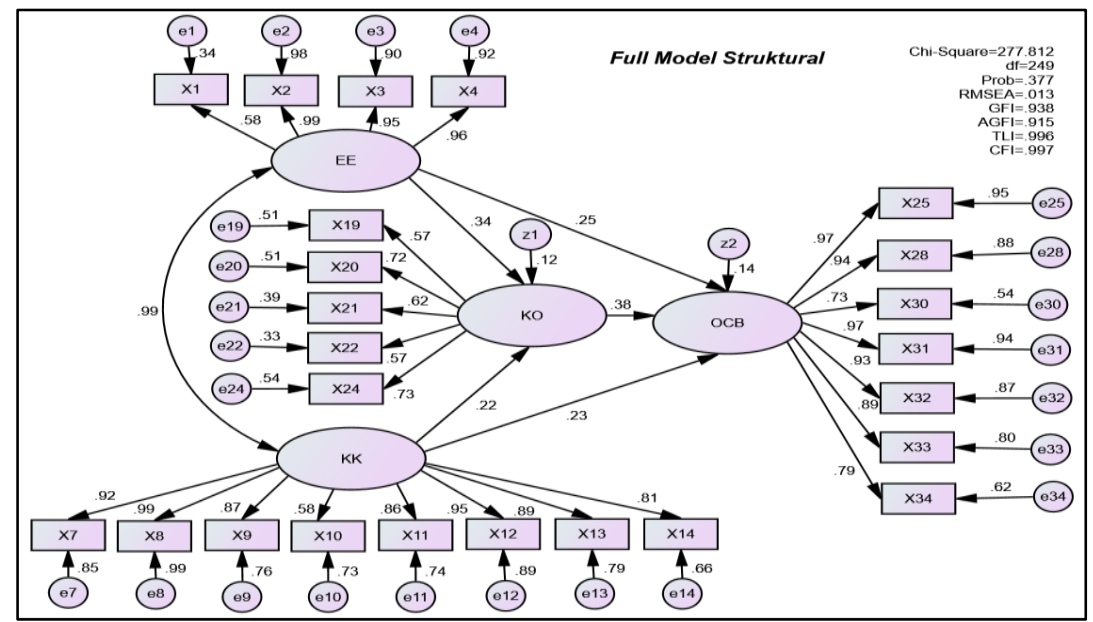

Figure 2: Full SEM Model

Source: Primary data processed

After all the assumptions have been met, hypothesis testing will be carried out as proposed in the previous chapter. Testing the five hypotheses of this study was carried out based on the Critical Ratio (C.R.) value of a causal relationship from SEM processing results as in table 3 and figure 2 .

Table 3. Hypothesis Testing

\begin{tabular}{cccccccc}
\hline & Path & & Estimate & SE & CR & P & Description \\
\hline EE & $--->$ & KO & .473 & .111 & 4.250 & $* * *$ & support \\
K.K. & $--->$ & KO & .395 & .109 & 3617 & $* * *$ & support \\
E.E. & $--->$ & OCB & .560 & .128 & 3057 & $* * *$ & support \\
K.K. & $--->$ & OCB & .182 & .537 & 2,948 & .002 & support \\
K.O. & $--->$ & OCB & .664 & .222 & 2,993 & .003 & support \\
\hline$* * *=$ & significance at 0,000
\end{tabular}

Source: processed primary data, 2020

Table 3 shows the hypothesis testing results; The probability of significance is lower than $5 \%$ for any relationship between the hypothesized variables. It can be concluded that all of the five hypotheses are significant, which is supported by the sample data.

\section{DISCUSSION}

The analysis of team member engagement on organizational commitment at the Islamic Boarding School obtained significant results. These results show that the higher the employee engagement at Islamic Boarding School, the higher the organizational commitment. This study supports Puspadewi (2016), which explained that employee engagement significantly affects organizational commitment. Employees who have bonded with the company will have a solid attachment to the organization and have a low tendency to leave. Furthermore, Saragih \& Margaretha (2013) suggested that employees with a high engagement level will have a high commitment to work and organization. Research results 
Haryanto et al. (2018) explained that employee engagement significantly affects organizational commitment.

In line with Moyo, Ngqabutho's (2019) research, the current study recognizes the organization's commitment as a psychological state consisting of affective, normative, and sustainable obligations, and it is associated with a variety of factors. The findings of this study show that employee engagement, transformational leadership, and organizational communication have a significant positive impact on organizational commitment. Organizations must identify critical drivers of organizational commitment and ensure their ongoing assessment to drive practical organizational commitment among employees.

The results showed that the Islamic Boarding School employees felt proud of the work they had done and remained diligent at work without feeling threatened by the challenges they faced. Other findings showed that employees find it difficult to separate themselves from work, meaning that not all employees feel happy with themselves being immersed, highly concentrated, and serious in doing their job. In this case, there is a need for stimulants, such as giving rewards to employees who can concentrate more and feel happy that they are immersed in the work.

Based on the analysis, it is known that employees' job satisfaction has a significant effect on organizational commitment. These results mean that the higher the job satisfaction of employees at the Islamic Boarding School in Kuningan, the higher the corporate loyalty. When employees are satisfied with their work conditions, they tend to work optimally by showing commitment to the organization. This study supports the research results conducted by Cahya Utama \& Wibawa (2016), which explains that job satisfaction has a significant effect on organizational commitment. Furthermore, Triwibowo \& Arsanti (2016) argue that some elements can build employee job satisfaction, and fulfilling these employees' needs and desires will increase their commitment. Job satisfaction that is maintained continuously will cause a feeling of commitment to the organization. Furthermore, Haryanto et al. (2018) explained that with job satisfaction with the conditions within the company, employees would be more enthusiastic at work and ready to give their best to support the improvement of company performance. It is also supported by Skiker, Calahan, Mkiker (2019) that there is a positive relationship between leadership style, Organizational Citizenship Behavior, job satisfaction, and organizational commitment.

Based on the results, the employees of the Islamic Boarding School in Kuningan were satisfied with their work environment. Still, not all employees felt competent with their ability to work. In this case, the Islamic Boarding School needs to pay attention to employee's competencies by providing opportunities for employees to learn and accept responsibilities and hold training and development programs to improve the employee's competencies.

Based on the results, it was found that employee engagement had a significant effect on Organizational Citizenship Behavior. These results mean the higher the employee engagement at Islamic Boarding School, the higher the Organizational Citizenship Behavior. If employees are already engaged in an 
organization where they worked, they will have an increased awareness to do extra to the job role and organization. This study's results support the research results conducted by Chhetri (2017), which shows that employee engagement has a significant effect on Organizational Citizenship Behavior. In line with research by Fauziridwan et al. (2018), which explained that the higher the employee engagement, the higher the OCB behavior of the SOE bank marketing staff in Purwokerto.

The research conducted by Mansoor (2012) stated that employee engagement positively influences organizational citizenship behavior. Furthermore, Sridhar \& Thiruvenkadam (2014) showed that employee engagement had a significant effect on OCB. Many employees of the Islamic Boarding School are not yet disciplined in terms of work attendance, so the boarding school needs to give punishment to employees who are late for work to prevent it become culture. Meanwhile, Boarding School employees maintain the proper name of the Pondok by always being careful about issues that can harm the organization.

Based on the analysis, it is found that employee job satisfaction significantly affects organizational citizenship behavior. This result means that the higher the job satisfaction of employees at Islamic Boarding School, the higher the Organizational Citizenship Behavior. Employees who are satisfied with their work tend to have high Organizational Citizenship Behavior because happy employees will work optimally and encourage positive behaviors such as helping colleagues, talking positively about the organization, and delivering performance beyond the minimum requirements. This study supports the research results conducted by Nwibere (2014), which shows that job satisfaction has a significant effect on OCB among employees of the Niger Delta University, Nigeria. In line with the research results by Cahya Utama \& Wibawa (2016), job satisfaction has a significant effect on Bali Rani Hotel employees. Triwibowo \& Arsanti (2016), in their research, explain that satisfied employees are more likely to do their more than the job description should be because they want to repay their positive experiences at work. In simple terms, it can be understood that when individuals feel satisfied with their work, the resulting OCB behavior is a form of personal appreciation for the organization where the individual works and has provided a sense of satisfaction to the individual. Soelton (2020) offers implications for employee job satisfaction positively affecting organizational citizenship behavior.

Based on the analysis results, it is found that organizational commitment has a significant effect on OCB. This result means that the higher the organizational commitment of employees at Islamic Boarding School, the higher the OCB. Thus, organizational commitment is needed by Islamic Boarding School employees because it is a factor that can strengthen employee's OCB. This study's results support Zayas-Ortiz et al. (2015), which shows that organizational commitment significantly affects OCB. It is in line with the research results by Muhajir \& Arisandra (2018), which explains that organizational commitment has a significant effect on Organizational Citizenship Behavior (OCB) on SME employees in Lamongan. The finding is also in line with Cetin, Gürbüz, and Sert 
(2015) when the organization's commitment as a moderator variable positively correlates with Organizational Citizenship Behavior.

Furthermore, in their research, Triwibowo \& Arsanti (2016) explained that employees with high organizational commitment would do not only the tasks that have become their obligations but will voluntarily do things that can be classified as extra effort. According to Meilina (2017), normative commitment is a commitment at the lowest level because this commitment is only based on workers' obligation to join the organization. For example, due to contractual ties, pressure from family, socialization, and others.

\section{CONCLUSION AND FURTHER STUDIES}

From the results of data processing and analysis, it can be seen that employees have high levels of employee engagement, job satisfaction, organizational commitment, and organizational citizenship behavior. Employee engagement affects organizational commitment and OCB, and then job satisfaction affects organizational commitment and OCB. Besides, the organization's commitment also involves the OCB of Islamic Boarding School. There is the need to provide stimulants such as giving rewards to employees who can work well. In increasing employee job satisfaction, it is necessary to pay attention to employee competence by offering employees opportunities to learn and accept responsibility and hold training and development programs to improve employee's competence. To increase employee's OCB, Boarding School needs to provide punishment to employees who are late for work so that the behavior does not become a culture. Besides, it is necessary to maintain employees with high affective commitment because they tend to have high loyalty to the organization and are willing to do anything. Further research is expected to take a wider research area and a larger population. Besides, it is expected to develop other independent variables outside of this research model, especially for other factors that can improve organizational citizenship behavior, such as corporate culture, work motivation, and leadership style.

\section{REFERENCES}

Aldag, R., \& Reschke, W. (1997). Employee Value Added: Measuring Discretionary Effort and Its Value to the Organization. Center for Organization Effectiveness, Inc., 1-8.

Amanda, A. R. (2014). Pengaruh Employee Communication Terhadap Organizational Citizenship Behavior yang dimediasi oleh Employee Engagement Pada Karyawan di beberapa Fakultas Universitas Trisakti Jakarta. Jurnal Manajemen Dan Pemasaran Jasa, 7(1), 111-128.

Arikunto, S. (2006). Prosedur Penelitian Suatu Pendekatan Praktik. Jakarta: Rineka Cipta. 
Bishop, James W, Aldag, R., \& Reschke, W. (1997). Employee Value Added: Measuring Discretionary Effort and Its Value to the Organization. Center for Organization Effectiveness, Inc., 1-8.

Amanda, A. R. (2014). Pengaruh Employee Communication Terhadap Organizational Citizenship Behavior yang dimediasi oleh Employee Engagement Pada Karyawan di beberapa Fakultas Universitas Trisakti Jakarta. Jurnal Manajemen Dan Pemasaran Jasa, 7(1), 111-128.

Arikunto, S. (2006). Prosedur Penelitian Suatu Pendekatan Praktik. Jakarta: Rineka Cipta.

Bishop, James W, Prabagaran, Nalin, Daily, Bonnie F. Employee Support and Their Perceptions of Quality and Environmental Performance: The Role of Citizenship Behavior.,

Journal of Managerial Issues. Winter2020, Vol. 32 Issue 4, p421-439. 19p.

Buhali, G. A., \& Margaretha, M. (2013). Pengaruh Work-Family Conflict Terhadap Komitmen Organisasi: Kepuasan Kerja sebagai Variabel Mediasi. Jurnal Manajemen, 13(1), 15-34.

Cahya Utama, D. P. P., \& Wibawa, I. M. A. (2016). Pengaruh Kepuasan Kerja Terhadap Komitmen Organisasi dan Organizational Citizenship Behavior Pada Karyawan Bali Rani Hotel. E-Jurnal Manajemen Unud, 5(4), 2511-2543.

Cetin, Sahin, Gürbüz, Sait, Sert, Mahmut. (2015). A Meta-analysis of the Relationship between Organizational Commitment and Organizational Citizenship Behavior: Test of Potential Moderator Variables. Employee Responsibilities \& Rights Journal. Dec2015, Vol. 27 Issue 4, p281-303. 23p. 6 Charts.

Chhetri, S. B. (2017). Predictors and Outcomes of Employee Engagement: Empirical Study of Nepali Employees. Journal of Business and Management Research, 2(1), 14-32.

Darmawati, A., \& Indartono, S. (2015). Pengaruh Kepuasan Kerja Terhadap Organizational Citizenship Behavior Dengan komitmen Organisasi Sebagai Variabel Mediasi. Jurnal Ilmu Manajemen, 12(2), 49-64.

Darto, M. (2014). Peran Organizational Citisenship Behavior (OCB) Dalam Peningkatan Kinerja Individu di Sektor Publik: Sebuah Analisis Teoritis dan Empiris. Jurnal Borneo Administrator, 10(1), 110-134.

Fanani, I., Djati, S. P., \& Silvanita, K. (2018). management journal. Fundamental Management Journal, 1(1), 40-53.

Fauziridwan, M., Rabiatul adawiyah, W., \& Ahmad, A. A. (2018). Pengaruh Employee engagement dan Kepuasan Kerja Terhadap Organizational Citizenship Behavior serta Dampaknya Terhadap Turnover Intention. Jurnal Ekonomi, Bisnis, Dan Akuntansi (JEBA), 20(1), 1-23.

Ferdinand, A. (2014). Metode Penelitian Manajemen (Edisi 5). Semarang: Badan Penerbit Universitas Diponegoro.

Ghozali, I. (2017). Model Persamaan Struktural (Edisi 7). Semarang: Badan Penerbit Universitas Diponegoro.

Handoko, H. (2012). Manajemen Personalia \& Sumberdaya. Yogyakarta: BPFE. Haryanto, R., Fathoni, A., \& Minarsih, M. M. (2018). Pengaruh Karakteristik Pekerjaan, Employee Engagement dan Motivasi Terhadap Komitmen 
Organisasi dengan Kepuasan Kerja sebagai Intervening Pada PT. Eka Farma di Semarang. Journal Of Management, 1-18.

Kiker, D. Scott, Scully Callahan, Judith, Kiker, Mary Brlek. Exploring the Boundaries of Servant Leadership: A Meta-Analysis of the Main and Moderating Effects of Servant Leadership on Behavioral and Affective Outcomes. Journal of Managerial Issues. Summer2019, Vol. 31 Issue 2, p172197. 26p.

Kiswari, Y., Fathoni, A., \& Minarsih, M. M. (2016). Pengaruh Kepuasan Kerja, Persepsi Pegawai dan Komitmen Organisasi Pegawai Terhadap Organizational Citizenship Behavior. Journal Of Management, 2(2).

Kusumaninggati, Mukhtar, M., \& Sujanto, B. (2018). The Influence of Self Efficacy , Job Satisfaction and Organizational Commitment Toward Organizational Citizenship Behavior (OCB) of Teachers Of Private Vocational Schools in South Jakarta. International Journal of Scientific Research and Management (IJSRM), 06(06), 406-414.

Luthans, F. (2011). Perilaku Organisasi (Edisi 12). New York: Mc Graw.

Macey, W. H., Schneider, B., \& Barbera, K. M. (2011). Employee Engagement: Tools for Analysis, Practice, and Competitive Advantage. John Wiley \& Sons, 31.

Meilina, R. (2017). Pelayanan Publik dalam Perspektif MSDM (Tinajuan dari Dimensi OCB, Kepuasan Kerja dan Komitmen Organisasi). Kediri: Fakultas Ekonomi Universitas Nusantara PGRI.

Muhajir, A., \& Arisandra, M. L. (2018). Dampak Kepuasan Kerja dan Komitmen Organisasi Terhadap Organizational Citizenship Behavior (OCB) Pada Karyawan Usaha Kecil dan Menengah (UKM). HUMANIS, 10(1), 1-10.

Narmeen Mansoor, Hassan Danial Aslam, Tasawar Javad, Fawad Ashraf,Farooq Shabbir (2012). Exploring Organizational Citizenship Behavior and its Critical Link to Employee Engagement for Effectual Human Resource Management in Organizations . Mediterranean Journal of Social Sciences, Vol 3, Iss 1 (2012).

Nugraha, I. P. S., \& Dewi Adnyani, I. G. A. (2018). Pengaruh Budaya Organisasi, Komitmen Organisasi, dan Kompetensi Terhadap Organizational Citizenship Behavior Pada SETDA Kota Denpasar. E-Jurnal Manajemen Unud, 7(1), 1-28.

Nwibere, B. M. (2014). Interactive Relationship Between Job Involvement, Job Satisfaction, Organizational Citizenship Behaviour, And Organizational Commitment In Nigerian Universities. International Journal of Management and Sustainability, 3(3), 321-340.

Panggabean, S. M. (2004). Manajemen Sumber Daya Manusia. Bogor: Ghalia Indonesia.

Pavalache-ilie, M. (2014). Organizational citizenship behaviour, work satisfaction and employees' personality. In Procedia - Social and Behavioral Sciences (Vol. 127, pp. 489-493). Elsevier B.V. 
Puspadewi, U. I. (2016). Analisis Tentang Employee Engagement Pada Perusahan Jasa (Studi Pada Karyawan Patra Jasa Convention Hotel Semarang). Dipnegoro Journal Of Management, 5(3), 1-14.

Putrana, Y., Fathoni, A., \& Warso, M. M. (2016). Pengaruh Kepuasan Kerja dan Komitmen organisasi Terhadap Organizational Citizenship Behavior Dalam Meningkatkan Kinerja Karyawan Pada PT. Gelora Persada Mediatama Semarang, 2(2).

Putri, A. (2018). Pentingnya "Organizational Citizenship Behavior" dalam Organisasi. Retrieved from www.kompasiana.com

Robbins, S. P., \& Judge, T. A. (2015). Perilaku Organisasi (Edisi 16). Jakarta: Penerbit Salemba Empat.

Robbins, S. p, \& Coulter, M. (2010). Manajemen (Edisi ke-1). Jakarta: Penerbit Erlangga.

Saragih, S., \& Margaretha, M. (2013). Anteseden dan Konsekuensi Employee Engagement : Studi pada Industri Perbankan (pp. 1-22).

Schaufeli, W. ., \& Bakker, A. . (2003). UWES - Utrecht Work Engagement Scale: Test Manual. Unpublished Manuscripy: Department of Psychology, Utrecht University.

Soelton, M. (2020). The The Implication Of Job Satisfaction That Influence Workers To Practice Organizational Citizenship Behavior (Ocb) In The Work Place . Archives of Business Research, 8(5), 33-48.

Sridhar, A., \& Thiruvenkadam, T. (2014). Impact of Employee Engagement on Organization Citizenship Behavior. BVIMSR's Journal Of Management and Research, 6(2), 147-155.

Triwibowo, W., \& Arsanti, T. A. (2016). Pengaruh Kepuasan Kerja Terhadap Organizational Citizenship Behaviour (OCB) Dengan Komitmen Organisasi Sebagai Variabel Mediasi. In Prosiding Seminar Nasional Multi Disiplin Ilmu \& Call Papers UNISBANK (SENDI_U) Ke-2 (pp. 908-915).

Umam, K. (2010). Perilaku Organisasi. Bandung: CV Pustaka Setia.

Wibowo. (2016). Manajemen Kinerja (Edisi ke-5). Jakarta: Rajawali Pers.

Zayas-Ortiz, M., Rosario, E., Marquez, E., \& Gruneiro, P. C. (2015). Relationship Between Organizational Commitments and Organizational Citizenship Behaviour in a Sample of Private Banking Employees. International Journal of Sociology and Social Policy, 35(12), 9-106. 